\title{
The Evaluation of the Religious Educational Studies in Turkey in the Context of Critiques Directed at Jean Piaget's Language and Conceptual Development Theories*
}

\author{
Muhammet Mustafa Bayraktar \\ Ministry of National Education (MEB), Ankara, Turkey \\ Muhiddin Okumuşlar \\ Necmettin Erbakan University, Konya, Turkey
}

\begin{abstract}
Jean Piaget who was born on August 9, 1896 in Switzerland, studied the characteristics of children's language and thought and put four important periods of cognitive development forward. Piaget's cognitive development theory influenced the developmental stage theories that emerged in the fields, such as education, psychology, sociology, and morality. At the same time, the studies conducted in the field of cognitive development were used to determine the children's religious development stages by adapting them to the areas of religious education and religious development. On the other hand, Piaget attracted many researchers' attentions in terms of both the results achieved and the method providing these results obtained. In this process, a great deal of studies of evaluation and critique were done on the cognitive development theory. When the effects of the cognitive development theory are considered, it is necessary to follow the critiques directed at Piaget and to make evaluations in this direction. The aim of the study at this point is to evaluate the studies of religious education in Turkey in the context of the critiques directed at Piaget's views on language and concept.
\end{abstract}

Keywords: Jean Piaget, the cognitive development theory, critiques directed to Piaget, religious education in Turkey

\section{Introduction}

In order to evaluate the religious education studies in Turkey in the context of critiques directed at Piaget's views on language and concept development, it is necessary to put forward Piaget's opinions on this subject and then the critiques directed to Piaget on this subject. The relevant and accessible texts from the books, the articles, and the postgraduate thesis prepared in the field of religious education were taken in order to determine the extent to which Piaget influenced the religious studies in Turkey in terms of language and concept development. The text contents taken from the studies in religious education relating to Piaget's language and

\footnotetext{
* Acknowledgements: This article is produced from Muhammet Mustafa Bayraktar's 2017 doctoral thesis titled "Evaluation of the Studies in Religious Education in Turkey Within the Context of Criticisms Levelled at Jean Piaget's Theory of Cognitive Development." Necmettin Erbakan University, Institute of Social Sciences, Department of Philosophy and Religious Sciences, Department of Religious Education, Konya, Turkey. Thesis advisor: Professor Muhiddin Okumuşlar.

Muhammet Mustafa Bayraktar, Ph.D., teacher, Ministry of National Education (MEB).

Muhiddin Okumuşlar, Ph.D., professor, Department of Religious Education, Necmettin Erbakan University.
} 
concept development were tried to be interpreted in the context of critiques directed at Piaget. In this context, 20 studies from the religious education in Turkey were evaluated. Thus, the authenticity of the religious education studies in Turkey around Piaget's views on language and concept development was brought up to the agenda in the work.

\section{Piaget's Views on Language and Concept Development}

Piaget (1923) expressed that he found the assumptions about the child language claimed by Freud, Ferenczi, Jones, Spielrein, Neumann, and Stern deep and accurate about children's thoughts. However, he thought that it was interesting to highlight the problem of language function for the children aged six and over, too (Amsel \& Byrnes, 2002). For this reason, Piaget was in search of the methods and techniques that would enable to look at thinking and expression skills in children from different aspects.

He carried out one of these experiments in the "small house" class in J. J. Rousseau Institute. The classes in which the research was conducted were in the features that children can paint, build, model, play arithmetics, or closet drama. No restrictions were imposed on children in terms of speech and cooperation. Unless the children requested, the adults did not step in any work and in the formation of speech and playgroups, and they were not asked to continue to the activity unless they had a desire for continuity. Under these circumstances, two six-year-old boys were watched at certain hours during the day for a month and all their expressions were recorded exactly. By combining the children's sentences having the same meaning following the observation and recording, a text was created and categorized from all the sentences they said separately (Scholnick, 2002, p. 6).

Piaget divided all the statements of the subject into two parts that he called the egocentric (self-centered) and the "socialized language" in that study. According to Piaget (1923), when a child uttered the statements in section one, he/she cared about neither whom he/she said nor who listened to them. He/she talked either for himself/herself or talked for the joy of adding someone to the action he/she was engaged in. This language is egocentric, because they talks only about himself/herself. The person opposite is randomly selected and only an ostensible interest is requested from him/her. The child is not in need of influencing the one opposite or teaching him/her something indeed. Piaget divided the egocentric language into three categories as repetition, monologue, and two-person monologue. He divided the socialized language into five categories as appropriate information, criticism, orders-wishes-threats, questions, and answers, too (Piaget, 2007, p. 9).

The general characteristics of the egocentric language have a feature that is not useful for transfering of the thought, but it is useful for tempting himself/herself to do something, supporting the thought, or substituting it. In a sense, this language is nothing more than the emergence of words taken through other people. In all language learning processes, a child confuses his/her own viewpoints with the ones belonging to others and does not know that he/she is imitating them, too. He/She talks to himself/herself as much as he/she talks to others. They are the statements showing the imagination overflow (Daiute, 2002, p. 216; Piaget, 2007, p. 9). It is regarded as a mutual monologue that a child does not think to talk to the person opposite and to be listened to by the answerer. Besides, he/she is not surprised at not responding of the answerer although he/she repeats his/her statements himself/herself and he/she continues to his/her action by speaking of himself without responding to the statements of the person opposite when his/her turn comes.

Piaget continued to observe the children aged four to seven spending time in the classroom of the children's house especially in terms of their language functions, and made some evaluations. Until a certain 
period, children think and behave more self-centered than adults. Since the sense of social life at these ages is not yet born, it is not expected that they will come together with the aim of cooperation. When children enter an environment that stimulates their desire to join in extemporarily through an educational play, they break up the silence more often than working adults (Nelson \& Shaw, 2002, p. 30). At first sight, they give an impression that they are sharing ideas with each other.

According to Piaget (1923), children cannot hide their thoughts except imagery (design) and symbolic thinking until the ages of seven, cannot keep the thought coming to mind in themselves, and cannot afford a verbal control. Since he/she has not met his/her ego latency, the child's verbal control is less than expected. The child uses a language that cannot clearly identify the nuances and perspectives and that is content with the confirmation or rejection continuously instead of reasoning. When talking, he/she does not have the intention and concern to be understood by others. For this reason, his/her talking has the characteristics of a monologue that does not concern the person opposite. He/she uses the language similar to the adults' language when he/she asks and wants (Piaget, 2007, p. 43). Before the age of seven, even when the child is not alone, he/she talks to himself/herself and resons in a self-centered quality. According to Piaget (1923), children between seven and eight years of age did not have a complete social life. A group of children in any class of "Kids' House" is like a type of community in which there is no work sharing, no centralization of the research or no common dialogue. It was observed that the social life in "Kids' House" passed through three radical stages (Jurczak, 1997, p. 315). It has been determined that until the age of five, a child does everything alone isolatedly from the society. From the age of five to seven and a half, there are temporary, irregular, and small groups consisting of only two children. Towards seven and eight years of age, the need of cooperation arises and the eccentric statements begin to lose their importance in this period.

After having studied on two children aged six in terms of language functions and on children aged four to seven in terms of conversational types and stages, Piaget also repeated the same study on different child clusters in order to study different personalities. Therefore, a roomful of children's dialogues were recorded. The statements recorded and examined are the ones that 20 or so children (boys and girls) aged four to seven uttered when they were in a certain place or when they passed by the same place. It was seen that the language characteristics of the 20 children who were examined reflected their character differences and they were also the result of the same functional needs, and there was a difference in quantity, not quality. It was seen that ordering, threatening, criticizing, and arguing increased in the bully ones and the monologues increased in the dreamer ones.

According to Piaget (1923), the co-operation on the abstract thought with real quarrelling was only a stage after the age of seven years old. He stated that children were not satisfied with a single thought on a particular subject until the seven and eight years of age and that this did not mean that children also think about the contradictory propositions. The children acquire convictions by monitoring each other. Sometimes, it can also be seen that these convictions conflict. In this sense, children are uninterested in the contradiction. When they pass from one point of view to another, they forget the point of view of the previous one. They accept one of the two opposing thoughts, and then, very sincerely, they pass on to the other forgetting the statement they uttered. According to Piaget (1923), the absence of this "conformity and coherence in the stamement" disappeared with the emergence of the actual argument stage. If there is a relationship between the child's action and thought, then it turned out that it was a habit of arguing that created the need to create a unity on him/her and the need to systemize his/her thinking. Piaget produced a study entitled "Comprehension of the 
statement between children aged six to eight and oral explanation" on language functions and speech types. Piaget (1923) observed the comprehension of the statement among children by monitoring how a child explains something to the other. According to Piaget's observations, until the ages of seven and eight, a child makes neither an explanation nor shows evidence to his/her peers by himself/herself (Garvey \& Hogan, 1973; Piaget, 2007). Even if he/she thinks about them, he/she cannot tell because of the influence of egocentrism on his/her language.

In fact, according to Piaget (1923), the reason why children cannot understand each other was that they think they understand each other. Children have a belief that adults can read their thoughts in their faces whether they try to express themselves or not, whether they show the desire or not. The source of this mentality is that a child thinks himself/herself in the center of the world (Piaget, 2007, p. 123).

According to Piaget (1923), the conversations between children had some special features. The statements uttered cannot be adjusted according to the viewpoint of the answerer and the answerer screens them according to his/her own interests instead of comprehending them as they are and changes them according to his/her previous views and information. At the beginning, dialogues among children are not enough to get the speakers out of their own egocentrism. They think they are understood without even realizing it, thus, they fall into countless mistakes in their conversation. According to Piaget (1923), until the children aged seven and eight did not make an explanation and did not show evidence to their peers since a child's language was influenced by egocentrism. In the communications with adults, children have a belief that their thoughts are read by the adults in their faces. The reason of not enduring the hardship of explaning the desires openly by children is this attitude. According to Piaget (1923), the source of this mentality was that a child saw himself/herself in the center of the world (Piaget, 2007, p. 115). In reference to these experiments, the fact that children give importance in their utterences to events rather than time or reason relations that connect events was gradually associated with egocentrism by Piaget.

Piaget (1923) regarded child's disinterest related to the "how" of events as the basis for the disagreement between his/her thought and language. He stated that expressing of the cause and effect relations wrong by the children results from the fact that "because" (univoque) was an indication of a more closed and irregular correlation denominating as "juxtaposition" rather than not showing a precise "cause-and-effect" dependence. In experiments, with reference to the characteristics explanations of children to each other, Piaget come to the conclusion it is difficult and incomprehensible for children to understand each other because each child thinks for himself/herself. One consequence of Piaget's experiments on expression skills in children is how objective they are when they talk to each other. A radical difference was identified between six to seven years old and seven to eight years old children in terms of objectivity efforts. It was seen in the performed experiments that the narrator did not want to repeat what he/she had heard authentically, and that he/she started a completely different story by himself/herself rather than repeating the thing he/she did not understand (Piaget, 1923). Thus, Piaget claimed that the effort put forth on stating the thougth and understanding others in an objective way emerged at the age of seven in children.

Piaget (1923) made a series of experiments and observations to detect the presence of syncretism in the child's conception. Piaget continued to explain his views on child perception through these experiments. There is an unexpected reason to lift all difficulties, or an amazing skill on finding an answer to all problems by assumption in a child's imagination. There can be no "why" that should remain unanswered in a child's eyes. As for the method conveying a child to the verbal conception takes shape in his/her mind as follows. A child 
compounds the words he/she understands and forms an entirety schema by leaving aside all the difficult words in a sentences. The entirety scheme makes the interpretation of the words that are not understood possible. In other words, the unknown word is interpreted based on the general scheme of the two sentences (Piaget, 2007, p. 168).

\section{Religious Education Studies in Turkey in the Context of Language and Concept Development}

Under this heading, it is emphasized that to what extent Piaget's views on language and concept development influenced the religious education in Turkey. Additionally, the text contents taken from the religious education studies in Turkey were tried to be evaluated in the context of critiques directed at Piaget about language and concept development. In this context, examples from the studies carried out in the field of religious education were discussed.

In Tosun's (2001, pp. 169-170) book entitled Introduction to Religious Education, he refered to Piaget on language and concept development related to the development of the religious thought. He stated that it was possible to think the religious development started with language development, but the religion was connected with the values. Similarly, Köylü (2004, pp. 97-98) refered to Piaget's remarks on language and concept development while putting forward the children's understandings of death in his paper named "The influence of death on children and death education" as follows:

Researchers studying the children's understanding of death generally use the cognitive development theories (mostly cognitive development theories developed by Jean Piaget). As is known, Piaget analyzed the mental development from the first childhood to the puberty and put forward many developmental stages. Even in the early cildhood (infancy), according to Piaget (1923), there were six different mental development stages. Piaget claimed that children would not be able to reach the abstract thinking stage in a real sense for a long time, even 10-year-old children could only reach the concrete operation stage with all their mental resources. Therefore, children can only understand the abstract concepts precisely in paralel with the death concept in adolescence period.

Following these statements, Köylü (2004) stated that it was not enough to try to explain the children's understanding of death only through mental development theories. He indicated that language and intelligence development was also an important part on children's understanding of death, and pointed out that children's language development required a long process. For this reason, he emphasized that children can only understand abstract words and concepts, such as love, death, God, and faith at the age of 12. In another example, Uysal (2006, p. 16) refered to Piaget's views on the language and concept development appearing in the cognitive development theory in his master thesis entitled "Forming the concept of righteousness in children in the preschool period and its relationship with religious education."

Besides, Okur (2011, p. 58) discussed the religious education issues in his master's thesis entitled "An Analysis of a Material for Religious Education in the Family," and indicated that children's language and conceptual development should be taken into consideration. Okur (2011) correlated the religious education in the family with Piaget's views as follows:

The topics in children's education books should be handled with consideration of children's developmental characteristics. These kinds of instructions will help children to understand the topic better and make permanent learning possible. Therefore, the topics in the books about the religious education in the family should be discussed relatedly to each other, and while discussing them the appropriate concepts for the language and concept level should be used. According to Piaget (1923), the children in the first stage of primary education are in the concrete operational stage. 
Abstract thinking just begins at the age of 12 completely. Therefore, the topics of the books for the religious education in the family prepared for the behaviors we want to develop in children in this period should be supported by concrete materials that will appeal to their development stage. In addition, the principles and articles that facilitate understanding and learning of the topics should be included.

In another example, İpşirli (2011, pp. 17-18) mentioned Piaget's language and concept development in his master's thesis entitled "The Basic Values in Three to Six Years Old Children's General and Religious Education" and made the following evaluation on the development of religious concept:

Learning the concepts is one of the most important elements of the mental development, and Piaget has also emphasized the importance of it. Under the guidance of Piaget, later psychologists examined the methods of concept development in children. As the mental development progresses, the child's world begins to turn into the adults' conceptual world and the child begins to regulate the perceptual stimuli in a healthy manner from the four years of age. One of the ways of doing this is to separate the stimuli into different classes or sets.

Continuing the evaluations, İpşirli divides the preoperational stage covering two to six years in terms of concept development. Ayaydın (2012, pp. 30-31) correlated Piaget's language and concept development with the religious thought and concept development in his master's thesis entitled "An Analysis of the Problems Related to Teaching Abstract Concepts in Religious Teaching." Ayaydın (2012) stated that the conceptual development moved from concrete to abstract, from simple to complex, and noted that concept development takes place with the words that were the names of objects in children. He stated that the learning of the abstract concepts would be easier as the education level increases, and that language development and cognitive development influence the concept learning in children. Ayaydın (2012) remarked that there might be differences in understanding abstract concepts between cognitively advanced children and those who did not, and made the following evaluation related to the development of religious concepts in children:

The formation and development of religious understanding in children is based on concepts. However, the learning of the abstract concepts requires higher level cognitive processing than the concrete ones and it takes place within the process. In classical concept teaching, a concept is given, the definition is made, and examples of this concept and those that are not are listed. However, only the memorization of the definition and the introduction of the concept by this way actualises a lower level of learning, the transfer from the ones learned before to the new ones cannot be carried out, and no binding is made between the informations. Even sometimes, in the lessons, such as religious culture and ethics knowledge, in which abstract concepts gain intensity, it is very difficult to define the concept as well. Due to these reasons, new methods should be applied to facilitate the teaching of concepts in the lessons.

In another example, Bilecik (2012, pp. 8-10) mentioned Piaget's language and concept development in his master's thesis entitled "An analysis of the verse translation in the 4th and 5th grade textbooks of religious culture and ethics knowledge in primary school according to the student perception levels." He made remarks on the development and teaching of the religious concept.

Similarly, Selçuk (1990, pp. 108-112) questioned what age a child gained the concept of God at in his paper entitled "Religious Motives in Child Education-Pre-school Age." In this context, he stated that children became aware of religious concepts beginning from three or four years of age parallel to their cognitive development. However, he stated that not only age but also maturation and environmental conditions influenced the undertanding of the concept of God in children. He also remarked that the concepts, such as God, angel, prophet, heaven, and hell are full of secrets for children in pre-school period. After Piaget's cognitive development theory in his book entitled Religious Motifs in Child's Education, Selçuk (1991, pp. 32-35) 
evaluated the development of religious thought in children with reference to this theory. In his statements here, Selçuk (1990) remarked that it was very difficult to understand the abstract religious concepts in the language of religion for children especially in the pre-operational period. Moreover, that children often can misunderstand these concepts. He stated that the religious thought made a progress and it was not easy to pass from the concrete though to the abstract thought. He also indicated that there might be a decrease with age in concrete thinking, but it would not disappear completely. However, he emphasized that abstract thinking can occur at the age of 11 and that it was only possible to think about abstract religious matters after 13-year-old. Likewise, Ay (1999, pp. 58-61) stated in his book entitled How Can I Tell My Children About God that children had a limited mental and language capacity and that religious information to be given without considering this situation would cause confusion in children's minds.

Doğan and Tosun (2002, pp. 105-119) stated that mental and conceptual teaching of religion was applicable for children in the 11-12 age in their books entitled Teaching of Religious Culture and Ethics Knowledge. Akyürek (2003, pp. 6-8, 130-131, \& 151) stated that the development of religious thought depended on the development of the language of religion having symbolic and metaphorical abstract features and this feature of the language of religion should not be ignored when religious concepts are taught in his Ph.D. thesis entitled "Teaching concepts in religious education." He remarked that students had difficulty in understanding abstract religious concepts and that teachers also had difficulty in describing these concepts. In addition, he stated that religious information to be given regardless of children's limited mind and language capacities might lead to conceptual confusion in children and might even lead the child to fill the content of concepts incorrectly. He stated that children made sense of concepts in accordance with their developmental characteristics and that this ability increased as their development progresses.

Şimşek (2004, pp. 212-213) discussed the development of the language in children within the context of Piaget's views on language and concept development in his paper entitled "The Characteristics of Religious Development in Childhood and Religious Education." He stated that children's questions within the scope of abstract religious concepts should be answered in accordance with their mental development. Mehmedoğlu (2005, pp. 68-69) evaluated the perceptions of the school children aged seven to 11 on religious concepts in his book titled Moral and Religious Development, and mentioned Piaget's views on this subject. Besides, he stated that it was difficult for children to understand abstract concepts due to the mental confusion they had experienced in this period.

Similarly, Biberci (2010, pp. 12-14) stated that children in pre-operational period cannot understand abstract concepts in his master thesis entitled "Teaching of Values of Affection and Compassion in the Light of Hadiths in Two to Seven Years Old Children.” Güner (2010, p. 60) included Piaget's views on language and concept development in his master thesis entitled "Ethics Learning Domain in Religious Culture and Ethics Knowledge Coursebook." He stated that students in the 14th grade level were unable to understand abstract concepts since they were in the stage of concrete operations according to Piaget's theory of cognitive development. Kurtekin (2013, p. 127) included Piaget's views on language and concept development in his master thesis entitled "Religious and Ethics Values in the Case of 10 Popular Books Among yhe 100 Basic Works Recommended by the Ministry of National Education." He implied that abstract concepts were in the cloak of secrecy for early-aged children.

However, it is also seen that in some religious education studies, there are overlapping evaluations of critiques directed at Piaget about language and concept development. For example, Oruç (2013, pp. 978-979) 
refered to the critiques of religious development theories developed within the framework of Piaget's theory of cognitive development in his paper entitled "Religious Education in the Context of Early Childhood Religious Development Theories." He stated that it was wrong asking children questions about religious concepts or making evaluations concerning children's religious developments by having them draw pictures about religious subjects while developing religious development theories. Following these statements, Oruç (2013) carrieed out the following evaluation on religious development theories based on Piaget's views on language and concept development:

In the early childhood religious development theories, especially in the Piagetian and post-Piagetian researches, one or several methods, such as asking questions to the child directly, asking him to draw a picture of the story after a brief narration, reading stories about God, or writing letters to God were used. It is clear that making an evaluation in this way cannot verbalise many feelings that the child feels, and that researches carried out with this method manipulate the education. Because children lack the cultural contribution and knowledge base adults have, therefore, it cannot be expected from them to express their feelings immediately in a more abstract field such as religion or God. Principally, Goldman tries to explain that children's thoughts separate from the cultural contribution provided by adults and religious education in the light of Piaget's animism debate which is often seen in early childhood. According to Boyer and Walker (2000), Goldman's researches were based on a normative record of religious representations. Shortly, his recent works criticize Piagetian theories on approaching to children by isolating them from the ontological background, on evaluating them only with reference to the visibles and religious concepts.

Doğan and Tosun (2002, pp. 105-119) stated that children were interested in abstract religious concepts in pre-school period, and children aged nine to $10 \mathrm{know}$ what abstract religious concepts mean under the heading of religious development and concept teaching in their book entitled Teaching of Religious Culture and Ethics Knowledge. They remarked that after the age of six years old, a child was in search of a conscious and realistic religion. They emphasized that children in this period were able to judge on certain issues and that there was a transition from concrete to abstract in their minds. They stated that children at the age of seven years old can explain God by themselves in short and that they had the idea that God was the creator of all beings.

Likewise, Akyürek (2003, pp. 6-8, 130-131, 151) remarked in his Ph.D. thesis entitled "Concept Teaching in Religious Education" that special teaching principles and methods to teach religious abstract concepts had not yet been developed. Köylü (2004, pp. 97-98) stated in his paper entitled "The influence of death on children and death education" that those who researched for the understanding of death of children generally use Piaget's cognitive development theory. Based on Piaget's cognitive development theory, Köylü (2004) highlighted highlighted that it was not sufficient to assert that children cannot develop an understanding of death till abstract operational stage and that it was not sufficient to try to explain children's understanding of death with the cognitive development theory in this way. Additionally, he stated that it was possible to make a deduction that children aged 10-12 do not understand the abstract words at all or that they do not attribute a meaning to the abstract words and concepts.

In Yiğit's (2006, pp. 186-187) paper entitled "Religious Educatin in the Family in Accordance With the Child's Developmental Characteristics and Communication Principles," she stated that children can learn the religious words that they heard in their first childhood through their environment and various ways of communication. Oruç (2011, p. 192) correlated the language development with the teaching belief in the Prophet in the book entitled Religious Education of the Child in the Preschool Period. He stated that the life stories of the prophets can be told to children beginning from two or three years of age in parallel with language development. 
Looking at the textual content examined as an example, the principles and ideas put forward in religious education studies in Turkey in the context of Piaget's language and concept development are as follows:

1. According to some studies, children have a limited mental and language capacity in terms of religious education;

2. It is very difficult for children to understand many concepts, such as God, prophet, angel, djinn, devil, sin, good deed, destiny and fate, heaven, hell, death, and goodness especially in the pre-school period;

3. Religious concepts are difficult for children to understand, and for parents and teachers there are difficult and abstract concepts to describe to teach as well;

4. The development of religious understanding and thought in children is directly related to the development of the language of religion which have the characteristics of symbolic, metaphorical, and abstract features;

5. Abstract thinking is possible only at the age of 11 and in religious concepts, it can occur around the chrilden aged 13;

6. Even if the children do not yet fully understand some religious concepts, they are interested in them and willing to learn these concepts;

7. An appropriate religious education to children's development stage must be provided within the framework of the children's interest in learning religious concepts;

8. Religious information to be given to children without thinking of their limited mind and language capacities may cause a conceptual confusion in the mind.

\section{Critiques Directed to Piaget on Language and Concept Development}

Piaget initiated the cognitive development with the language development and evaluated the cognitive development with verbal methods. Piaget's initiation of the cognitive development in parallel with the language development led to the critiques about his evaluation on thought through language at the same time (Lourenço \& Machado, 1996). Critics indicated that Piaget was mostly used clinical methods and that his researches were about verbal techniques. At the same time, they criticized Piaget for not mentioning the language in the technical description of concrete thought at all. Researchers (McGarrigle \& Donaldson, 1974; Gelman \& Gallistel, 1978; McGarrigle, Grieve, \& Hudges, 1978) asserted that conceptual development would manifest itself in a purer way when Piaget's oral reasoning on cognitive tasks was removed.

Indeed, these investigations (Markman, 1973; Levin, Israeli, \& Daron 1978; Acredolo \& Acredolo, 1979; Bullock \& Gelman, 1979; Ennis, 1982; Brainerd \& Knigma, 1984; Ojose, 2008) carried out in the direction of these claims and critiques showed that children aged five to six (or even smaller) were more likely to have reasoning and conceptual competencies and that children were prone to many cognitive characteristics of the concrete operational stage.

It is seen that other performed researches on children's competence (Zimmerman \& Whitehurst, 1979; Zimmerman \& Blom, 1983a, 1983b; Stiles-Davis, 1988; Bartsch \& Wellman, 1988; Sophian, 1988; English, 1993; Fabricius \& Wellman, 1993) did not support Piaget. For example, according to the results that Rosenthal and Zimmerman (1978) found in their researches, it was seen that children in the pre-operational stage successfully completed the cognitive features of the concrete operational stage after the training including oral expression and modeling.

In another study, as far as Köylü (2004, pp. 100-101) narrated that Vianello (1992) conducted extensive research on the understandings of death by taking children's developmental stages into account, which gave the 
following information on the results of the research: The understanding of death by children emerges in earlier years contrary to previous research results. Even children at the age of two and three years old, although they are not very meaningful, have some knowledge of death, and are aware of it. Even children under three years of age, it is seen that there is a feeling of confusion or mercy when an animal or an insect dies. Vianello (1992) also indicated in his research that children at that age comprehend that death was different from sleep or disease, that they defined death as the opposite of life, and that they saw weapon, knife, accident, and especially ending of life as the reason of death. Children can talk not only about the death of animals, but also about the death of adults and children.

Piaget was criticized for underestimating children's competencies for concept development, as well as for describing child language as a egocentric nature. For example, Wertsch and Kanner (1992) who studied child language and thought criticized Piaget for trivialising the cultural content generally, and the language in particular. Similarly, Vygotsky (1962), a socio-cultural researcher and a linguist, criticized Piaget in terms of egocentrism and egocentric speech in child. He argued against Piaget's views on egocentric speech in child, and stated that the egocentric structure in child language was a specific function.

Some psychologists (Borke, 1978; Murray, 1983; Montangero, 1985; Furth, 1986; Davidson, 1992) working on developmental psychology also criticized the lasting egocentric language that Piaget attributed to child. In similar studies conducted in the direction of these critiques (Mueller, 1972; Garvey \& Hogan, 1973; Rubin, 1973; Keenan, 1974), it was asserted that children can use language in the context of social interaction from the two years of age, and therefore, it was more appropriate to define children's language as socio-centric instead of egocentric. Other studies (Mays, 2000; Furth \& Youniss, 2000; Moessinger, 2000; Mays \& Smith, 2001; Daiute, 2002) that evaluated Piaget in the sociological context in this respect were conducted as well.

In this context, Keenan (1974) studied the speech of twins at age of three in his study and found that only a small percentage $(6 \%)$ of children's speech was not for the listeners (egocentric). Piaget's self-centered approach to the child's language was reworked not only in small children, but also in adolescents and adults. Contrary to Piaget's claim, it is also stated that the egocentrism cannot be defined by low intelligence (McDonald, 2002, p. 43).

\section{Conclusion and Evaluation}

In this study, it was tried to evaluate the religious education studies in Turkey in the context of critiques directed at Piaget's language and concept development. When we look at religious education studies in Turkey, it is seen that Piaget's views on language and concept development influenced the subjects on religious language in children, religious thought, and concept development.

In many religious education studies in Turkey, it is seen that evaluations were made on the critiques directed to Piaget on language and concept development are not taken in consideration, so that children have a limited mental and language capacity in terms of religious education for this reason, that children do not understand abstract concepts in pre-school period and that they can think through religious concepts only after the age of 13 years old. The fact that the results revealing children's competencies in the researches conducted in the direction of critiques directed at Piaget about language and concept development is not taken into consideration has led up to conservative evaluations regarding the religious concept developmentof children. On the other hand, it seems that only a few religious education studies refer to the cognitive competencies revealed in criticism studies directed at Piaget. 
From this point of view, in the context of criticism directed at Piaget, it is seen that there are two types of studies in the literature of religious education in Turkey. It is seen that several critiques directed at Piaget were refered in a small number of religious education studies, and a universal and absolute truth was attributed to Piaget's views in the rest of them. In this context, the critiques directed at Piaget should be discussed in religious education studies in Turkey profoundly and holistically.

\section{References}

Acredolo, C., \& Acredolo, L. P. (1979). Identity, compensation, and conservation. Child Development, 50(2), 524-535.

Akyürek, S. (2003). Din ögrretiminde kavram öğretimi (Concept teaching in religious education) (Doctor thesis, Erciyes Üniversitesi, Kayseri).

Amsel, E., \& Byrnes, P. J. (2002). Language, literacy, and cognitive development: The development and consequences of symbolic communication. London: Lawrence Erlbaum Associates Publishers.

Ay, M. E. (1999). Çocuklarımıza Allah'ı nasıl anlatalım? (How shoukd our children tell Allah?). İstanbul: Timaş Yayınları.

Ayaydın, N. (2012). Din ögretiminde soyut kavramların ögretilmesiyle ilgili problemlerin incelenmesi (Examining the problems related to the teaching of abstract concepts in teaching religion) (Master's degree thesis, Marmara Üniversitesi, İstanbul).

Bartsch, K., \& Wellman, H. (1988). Young children's conception of distance. Developmental Psychology, 24(4), $532-541$.

Biberci, F. (2010). 2-7 Yaş arası çocuklarda sevgi ve merhamet değerlerinin hadisler ışı̆̆ında ögretimi (Teaching the values of love and compassion in the light of the habits in children aged 2-7) (Master's degree thesis, Selçuk Üniversitesi, Konya).

Bilecik, S. (2012). İlköğretim din kültürü ve ahlak bilgisi 4. ve 5. sınıf ders kitaplarındaki ayet çevirilerinin öğrenci algı düzeylerine göre incelenmesi (Investigation of verse translations in primary and secondary school textbooks of religious culture and ethics according to student perception levels) (Master's degree thesis, Necmettin Erbakan Üniversitesi, Konya).

Brainerd, C., \& Kingma, J. (1984). Do children have to remember to reason? A fuzzy-trace theory of transitivity development, Developmental Review, 4, 311-377.

Borke, H. (1978). Piaget's view of social interaction and the theortical construct of empath. In L. Siegel, \& C. Brainerd (Eds.), Alternatives to Piaget: Critical essays on the theory (pp. 29-42), New York: Academic Press.

Bullock, M., \& Gelman, R., (1979). Preschool children's assumptions about cause and effect: Temporal ordering effect. Child Development, 50(1), 89-96.

Daiute, C. (2002). Social relational knowing in writing development. In E. Amsel, \& J. M. P. Byrnes (Eds.), Language, literacy, and cognitive development: The development and consequences of symbolic communication (pp. 193-232). Hillsdale, N.J.: Lawrence Erlbaum Associates.

Davidson, P. M. (I992). The role of social interaction in cognitive development: A propaedeutic. In L. Winegar, \& J. Valsiner (Eds.), Children's development within social context (pp. 19-37). Hillsdale, N.J.: Erlbaum.

Doğan, R., \& Tosun, C. (2002). İlköğretim 4. ve 5. sınıflar için din kültürü ve ahlak bilgisi dersi öğretimi (Instruction of religious culture and moral education courses for the 4th and 5th grades of primary education). Ankara: Pegem A. Yayıncilik.

English, L. (1993). Evidence for deductive reasoning: Implicitversus explicitre cognition of syllogistic structure. British Journal of Developmental Psychology, 11, 391-409.

Ennis, R. (1982). Children's ability to handle Piaget's propositional logic: A conceptual critique. In S. Modgil, \& C. Modgil (Eds.), Jean Piaget: Consensus and controversy (pp. 101-130 ). London: Holt, Rinehart, and Winston.

Fabricius, W. V., \& Wellman, H. M. (1993). Tworoads diverged: Young children's ability to judge distance. Child Development, 64, 399-414.

Furth, H. G. (1986). The social function of Piaget's theory: A response to apostel. New Ideas in Psychology, 1(1), 23-29.

Furth, H. G., \& Youniss, J. (2000). Reflections on Piaget's sociological studies. New Ideas in Psychology, 18, 121-133.

Garvey, C., \& Hogan, R. (1973). Social speech and social interaction: Egocentrism revisited. Child Development, 44, $562-568$.

Gelman, R., \& Gallistel, C. (1978). The child's understanding of number. Cambridge: Harvard University Press.

Güner, D. (2010). Illköğretim din kültürü ve ahlak bilgisi ders kitaplarında ahlak ögrenme alanında kullanılan ayetlerin din ögretimi açısından değerlendirilmesi (Evaluation of the verses used in the field of moral education in the religious education and moral textbooks of primary education in terms of religious education) (Master's degree thesis, Ankara Üniversitesi, Ankara).

İpşirli, S. (2011). 3-6 Yaş çocuğun genel ve din eğitiminde temel değerler (Three to six basic values of general and religious education of the child) (Master's degree thesis, Marmara Üniversitesi, İstanbul). 
Jurczak, P. M. (1997). The language and metaphor of Jean Piaget. Educational Psychology Review, 9(3), 311-318.

Keenan, E. (1974). Conversational competence in children. Journal of Child Language, 1(2), 163-183.

Köylü, M. (2004). Ölüm olayının çocuklar üzerine etkisi ve "ölüm eğitimi” (The effect of death on children and "death education"). OMÜIFD, 17, 95-120.

Kurttekin, F. (2013). MEB Tarafindan tavsiye edilen 100 temel eserden popüler olan on kitap örneğinde dini ve ahlaki değerler (Religious and moral values in ten books which are popular among the 100 basic works recommended by the MNE). (Master's degree thesis, Uludağ Üniversitesi, Bursa).

Levin, I., Israeli, E., \& Darom. E. (1978). The development of time concepts in young children: The relation between duration and succession. Child Development, 49, 755-764.

Lourenço, O., \& Machado, A. (1996). In defense of piaget's theory: A replayto 10 commen critism. Psychological Review, 103(1), 143-164.

Markman, E. (1973). Facilitation of part-whole comparisons by use of the collective noun "family." Child Development, 44, 837-840.

Mays, W. (2000). Piaget's sociology revisited. New Ideas in Psychology, 18(2), 261-275.

Mays, W., \& Smith, L. (2001). Harré on Piaget's sociological studies. New Ideas in Psychology, 19(3), 221-235.

McDonald, L. (2002). Egocentrism in older adults-Piaget's three mountains task revisited. Educational Gerontology, 28(1), $35-43$.

McGarrigle, J., \& Donaldson, M. (1974). Conservation accidents. Cognition, 3(4), 341-350.

McGarrigle, J., Grieve, R., \& Hughes, M. (1978). Interpreting inclusion: A contribution to the study of the child's cognitive and linguistic development. Journal of Experimental Child Psychology, 25, 528-550.

Mehmedoğlu, Y. (2005). Ahlâkî ve dinî gelişim (Moral and religious development) (3rd ed.). İstanbul: Morpa Kültür Yayınları.

Moessinger, P. (2000). Piaget: From biology to sociology. New Ideas in Psychology, 18, 171-176.

Montangero, J. (1985). Genetic epistemology: Yesterday and today. New York, N.Y.: The Graduate School and University Center, City University of New York.

Mueller, E. (1972). The maintenance of verbal exchanges between young children. Child Development, 43, 930-938.

Murray, F. (1983). Learning and development through social interaction and conflict: A challenge to social learning theory. In L. Liben (Ed.), Piaget and the foundations of knowledge (pp. 231-247). Hillsdale, N.J.: Erlbaum.

Nelson, K., \& Shaw, K. L. (2002). Developing a socially shared symbolic system in: Language, literacy, and cognitive development. In E. Amsel, \& J. P. Byrnes (Eds.), The development and consequences of symbolic communication (pp. 27-58). London: Lawrence Erlbaum Associates Publishers.

Ojose, B. (2008). Applying Piaget's theory of cognitive development to mathematics instruction. The Mathematics Educator, $18(1), 26-30$.

Okur, S. (2011). Ailede din eğitimine yönelik bir materyalin incelenmesi: Ev okulu ilmihal kitapları örneği (Examination of a material for religious education in the family: Example of home school textbooks) (Master's degree thesis, Erciyes Üniversitesi, Kayseri).

Oruç, C. (2011). Okul öncesi dönemde çocuğun din eğitimi (Religious education of the child in preschool period). İstanbul: Değerler Eğitimi Merkezi.

Oruç, C. (2013). Erken çocukluk dönemi dini gelişim teorileri bağlamında din eğitimi (Religious education in the context of early childhood religious development theories). Turkish Studies, 8(8), 971-987.

Piaget, J. (1923). Le langage et lapensee chez I'enfant. Neuchatel, Switzerland: Delachaux et Niestle.

Piaget, J. (2007). Çocukta dil ve düşünme (Language and thinking in children). (S. Esat, Trans.). Siyavuşgil, Ankara: Palme.

Rosenthal, T. L., \& Zimmerman, B. J. (1978). Social learning and cognition. New York, N.Y.: Academic Press.

Rubin, K. H. (1973). Egocentrism in childhood: A unitary construct? Child Development, 44(1), 102-110.

Scholnick, E. K. (2002). Language, literacy, and thought: forming a partnership. In E. Amsel, \& J. M. P. Byrnes (Eds.), Language, literacy, and cognitive development: the development and consequences of symbolic communication (pp. 3-26). Hillsdale, N.J.: Lawrence Erlbaum Associates.

Selçuk, M. (1990). Çocuk eğitiminde dini motifler — okul öncesi çağ (Religious motives in child education-pre-school age). Islamic Studies, 4(2), 105-117.

Selçuk, M. (1991). Çocuğun eğitiminde dini motifler (Religious motives in the child's education) (2nd ed.). Ankara: Türkiye Diyanet Vakfi.

Stiles-Davis, J. (1988). Developmental change in young children's spatial grouping activity. Developmental Psychology, 24(4), 522-531. 
Sophian, C. (1988). Early developments in children's understanding of number: Inferences about numerosity and one-to-one correspondence. Child Development, 59, 1397-1414.

Şimşek, E. (2004). Çocukluk dönemi dini gelişim özellikleri ve din eğitimi (Characteristics of religious development in childhood and religious education). Journal of Research in Linguistics, 4(1), 207-220.

Tosun, C. (2001). Din eğitimi bilimine giriş (Introduction to the science of religious education). Ankara: Pegem A. Yayınc1lık.

Uysal, A. (2006). Okul öncesi dönemde çocuğa doğruluk kavramının kazandırılması ve din eğitimi ile ilişkisi (To gain the concept of rightness to the child in pre-school period and to religion education) (Master's degree thesis, Marmara Üniversitesi, İstanbul).

Vianello, R., \& Tamminen, K., \& Ratcliff, D., (1992). The religious concepts of children, In R. Donald (Ed.), Handbook of children's religious education (pp. 56-81), Birmingham, Alabama: Religious Education Press.

Vygotsky, L. S. (1962). Thought and language. Cambridge, M.A.: The MIT Press.

Wertsch, J., \& Kanner, B. (1992). A socio-cultural approach to intellectual development. In R. Sternberg, \& C. Berg (Eds.), Intellectual development (pp. 328-349). Cambridge, England: Cambridge University Press.

Yiğit, A. (2006). Çocuğun gelişim özellikleri ve iletişim ilkeleri doğrultusunda ailede din eğitimi (Religious education in the family in line with the child's developmental characteristics and communication principles). OMÜIFD, 22, 179-203.

Zimmerman, B. J., \& Blom, D. E. (1983a). On resolving conflicting views of cognitive conflict. Developmental Review, 3, 62-72.

Zimmerman, B. J., \& Blom, D. E. (1983b). Toward and empirical test of the role of cognitive conflict in learning. Developmental Review, 3, 18-38.

Zimmerman, B. J., \& Whitehurst, G. J. (1979). Structure and function: A comparison of two views of the development of language and cognition. In G. J. Whitehurst, \& B. J. Zimmerman (Eds.), The functions of language and cognition (pp. 1-22). New York, N.Y.: Academic Press. 